DANMARKS GEOLOGISKE UNDERS $\varnothing$ GELSE

IV. R/EKKE. BD. 4. NR. 3

GEOLOGICAL SURVEY OF DENMARK. IV. SERIES. VOL. 4. NO. 3

\title{
Problems of the Early Post-Glacial Forest Development in Denmark
}

By

Johs. Iversen

With 1 plate

I kommission hos

C. A. REITZELS FORLAG (JØRGEN SANDAL)

KØBENHAVN 1960 
DANMARKS GEOLOGISKE UNDERSØGELSE

IV. RÆKKE. B D. 4. NR. 3

Geological Survey of Denmark. IV. Series. Vol. 4. No. 3

\section{Problems of the Early Post-Glacial Forest Development in Denmark}

By

Johs. Iversen

With 1 plate

C. A. REITZELS FORLAG (JØRGEN SANDAL) 
ANDELSBOGTRYKKERIET I ODENSE 


\section{CONTENTS}

Preface............................. 5

Introduction $\ldots \ldots \ldots \ldots \ldots \ldots \ldots \ldots \ldots$

The Pre-boreal and Boreal Forest Succession ... . . . 8

The Atlantic Climax Forest . . . . . . . . . . . . . 10

The Ulmus fall and the first appearance of farming . 14

Ivy (Hedera helix), Holly (Ilex aquifolium) and Mistletoe (Viscum album) in Atlantic and Subboreal times. . . . . . . . . . . . . . . . . . 21

Notes ... . . . . . . . . . . . . . . . . . . . . 26

Literature ....................... 31 


\section{Preface}

The present paper is a slightly extended copy of a lecture given before the Danish Geological Society January 1959. At the same meeting Dr. J. Troels-Smith read a paper, and both lectures were followed by a discussion. The author's contribution to the discussion is incorporated in the present account.

As the title indicates the paper deals with problems under debate. Because the author cannot, in this brief outline, express his hesitations in every single case, he wants to emphasize once and for all that the ecological interpretations are tentative only.Yet, he thinks the questions will have to be formulated and answered ecologically. However, the answers should be checked by an independent method. Fortunately this will be possible in many cases thanks to advanced methods now to hand, e.g. exact datings by radiocarbon.

A more complete discussion of the ecological background for the author's interpretation will be given in connection with a full report of our investigations in Draved forest. I take this opportunity to thank the Carlsberg Foundation for its generous support to these investigations, the present paper is largely based on experience derived from them.

Most of the problems of Post-glacial forest history have indeed been discussed in the well-known books by Firbas (1949) and Godwrn (1956), which in addition contain complete references. The reader is referred to these books.

The drawings have been most skilfully executed by Miss Ingeborg Frederiksen. 


\section{Introduction}

The first aim of pollen analysis was to obtain a comprehensive view of the most important phases of the Post-glacial forest evolution. This was achieved through KNud Jessen's zonation system, which in addition presents a broad relative chronology. The next objective-difficult yet fascinating-was to arrive at an ecological understanding of the pollen diagrams, i.e. to translate them into vegetational successions, and to find the underlying causes.

The problem may be approached from various angles. All interpretation must of course be based upon a thorough knowledge of the ecology and sociology of the tree species. Abundant information on the ecology of our trees is available, especially in forestal literature ${ }^{1}$ ). It is, however, often difficult to make use of this material for our particular purpose, especially because the pollen diagrams reflect the complex reaction of the tree communities to changes in the external factors. These questions are the subject of dynamic plant sociology, and contact with that field will form a good starting point for an interpretation of the pollen diagrams. Dynamic plant sociology has been rather neglected in Denmark where we have become accustomed to regard the plant communities as static and pay little attention to their change in time. The dynamic viewpoint, however, has for a long time characterized British-American plant geography (e. g. TANSLEY 1949).

The fundamental concepts of dynamic plant sociology are succession and climax. Wherever vegetation is not in equilibrium with its environments, succession will set in and continue until stability is reached in the final stage, the so-called climax vegetation. Under natural conditions vegetation on high ground in a low-lying country like Denmark would, broadly speaking, represent climax. However, man's all-round interventions have upset the balance everywhere; accordingly nearly all our plant communities are successional stages only, and true climax vegetation is an exception.

A great deal of criticism may be levelled at the climax theory in its original and rather dogmatic presentation by CLEments (1916). However, the concepts of succession and climax are sound provided that they are used as designation for actual conditions, and they are indispensable in vegetational history. Indeed, if these terms had not already been in existence, it would have been necessary to introduce them to meet the requirements of research in that field ${ }^{2}$ ).

We know very little of succession in our forests to-day, and opinions differ as to what may be properly called climax forests in this country. The difficulty is twofold. In the first place, forest successions are extremely slow: man's life is shorter than that of the trees, and the individual student will not live to see more than fragments of the successions. In the second place, human interference unceasingly interrupts or changes the normal course of the successions. Studies of the natural succession

1) Note 1 . See notes page 26 . 
of tree species can accordingly be carried out only in forests that are not subject to exploitation.

In 1947 the Geological Survey of Denmark began to organize a systematical investigation of the competition and the succession of tree species in Draved forest, near Logumkloster; with ample financial support generously provided by the Carlsberg Foundation. By courtesy of the authorities, parts of this state forest, covering a great range of soils, have been made available for the investigations. These greatly varying tree communities, some of which may still be regarded as quite natural, now remain completely untouched. Apart from pine, all important tree species of the Post-glacial still grow in this experimental area.

In our neighbouring countries more or less systematic studies of succession have also been instituted in totally protected forests, and the author has had an opportunity of late years to visit a number of them. Of supreme interest are, of course, the few remaining specimens of virgin forest in our temperate zone, especially in the mountains of southeastern Europe. A number of valuable studies of the virgin forests and their regeneration in southeastern Europe are available ${ }^{3}$ ).

Based on this succession research material and with due regard to the available literature on forest ecology and sociology, the author will now give a brief survey of the ecological conditions which may be regarded as essential to an understanding of the Post-glacial forest evolution.

The tree species may in the first place be divided into two types: "pioneer species" and "climax species". The pioneer species are distinguished by their high rate of reproduction. These species set their fruits already at an early age, abundantly and uniformly year by year. Seed dispersal is effective, and trees of this type appear readily wherever favourable new conditions for tree growth are created, for instance when lakes are filled in, when cultivated land is abandoned, after forest fires, etc. On the other hand, they are weak in competition because they require much light and have a relatively short life. Hence, they succumb in competition with other trees, and cannot form any stable forest type. Salix, Populus tremula, Betula and Sorbus are typical pioneer species.

The opposite of what has been said about the pioneer species applies to the climax species ${ }^{4}$ ). Their rate of reproduction and their seed dispersal are generally poor, they cannot keep pace with trees of the pioneer type in the initial stage; on the other hand, they are tenacious, once established, they stick their ground, and they will invariably suppress and supersede the pioneer species in the long run. The principal reasons are that they have a long life, attain a great height and endure and provide ample shade. Where, e.g., oak and birch grow up together, we shall in the course of less than 150 years have an unmixed oak forest. The birch will die from old age while the oak retains its youthful vigour, and the crowns of the oaks will soon close the holes in the canopy resulting from the death of the birches. Lime, beech and elm are still stronger than oak since, in addition to a long life, they have a greater shade endurance. Vaupell (1863) was the first who drew attention to the importance of the light factor in forest succession. Subsequent investigations by Boysen Jensen and others have sustained VAupell's view, that light demanding species will be replaced by shade tolerant trees in the long run, provtded that the conditions of growth are favourable to the latter ${ }^{5}$ ). 


\section{The Pre-boreal and Boreal Forest Succession}

The distinction between pioneer species and climax species facilitates the understanding of the first phases of the general Post-glacial forest evolution, that are so clearly reflected in the pollen diagrams (cf. fig. 7, plate). In the first place, there is generally a very striking, but short-lived, Juniperus maximum, which is followed by a less clearly marked aspen (Populus tremula) maximum. Then follows a long section in which birch predominates, mixed with pine, the frequency of which increases consistently. This Pre-boreal Birch period comes to an end with the immigration of hazel (Corylus avellana), which spreads rapidly and soon replaces birch, whereas pine proves to be rather more tenacious.

Basic in this characteristic succession is, of course, the sudden and radical climatic improvement which set in at about 8500 B.C. Nevertheless, it was not merely the change in temperature that was reflected in the individual phases of the succession; it would, e.g., be misleading to compare the Pre-boreal Birch period with the sub-arctic Birch region in Lapland. The temperature conditions must have been far more favourable in Pre-boreal time, perhaps as favourable as in our time. This is borne out int. al. by finds of the warmth demanding aquatic Cladium from the beginning of the Pre-boreal period. The birch-phase is, consequently, but one of the pioneer stages in a protracted succession; a forest type corresponding to the climatic conditions simply could not have come into existence because the tree species of the climax forest had not immigrated yet.

The stages of the first part of the Post-glacial forest development are determined by two factors, (1) the sequence of immigration and (2) competition among the tree species. The sequence of immigration in its turn depends upon two conditions: the distance from the nearest location of the species in question prior to the climatic change, and the speed with which they travel. There was no need for Juniperus to immigrate, the species grew everywhere in this country even before the climatic change set in, though stunted by the low temperature. Aspen and birch spread from refuges within the borders of this country, and pine was not far off either. On the other hand, the warmth-demanding species seem to have had their nearest habitats south of the Alps and the Pyrenees, and these east-west mountain ranges have formed an effective barrier to the north-bound migration of the warmth-demanding tree species. It took many centuries for them to reach our country, in the case of Fagus and Carpinus even millennia. As Firbas (1. c.) points out, there is no conformity between the sequence of immigration and the warmth-requirements of these tree species $\left.^{6}\right)$.

The formation of the successive stages is conditioned by competition among the immigrated tree species. As mentioned before, the varying light-requirement, the length of life and the height of the species chiefly determine the course of the competi- 
tion. The light-requirements of aspen, birch and juniper are rather similar, but the greater height growth of the former enables them to overshadow juniper; that is the reason that the juniper-stage is so short. Aspen (Populus tremula) is our most light-demanding tree species, and it has a particularly short life; the species is gradually superseded by birch and pine. The two latter species have approximately the same light-requirements, but birch is a more pronounced pioneer species than pine. It travels faster, for which reason it became established before pine. The latter, on the other hand, has a longer life, a fact which presumably explains its slow progress at the cost of the birch.

Hazel (Corylus avellana) is a shade tolerant shrub; its immigration put an end to the prevalence of birch and pine. Hazel thrives very well under the two latter, and their regeneration is impossible wherever an underwood of hazel exists. The shortlived birch succumbs first, and then the widely discussed Boreal hazel forest develops. There is no reason to regard this phase as anything but a seral stage in the succession. Hazel simply happened to be the first shade tolerant tree to immigrate; at the outset it met no serious competition. It was not until the immigration of elm (Ulmus ssp.) and lime (Tilia cordata) that conditions changed. These climax species are just as shade tolerant as Corylus, further they overtake hazel in height, and since hazel will not thrive in the shade of a lime-elm forest, it succumbs.

When Tilia immigrated at the transition to zone VI all the important climax species had arrived, with the exception of Fagus and, possibly, Quercus petraea ${ }^{2}$ ). Corylus, however, strongly resisted the expansion of Ulmus, Tilia and, particularly, the light-demanding Quercus; hence, centuries passed before stability was achieved, and the forest eventually reached climax. At the zone boundary VI-VII, according to Svend Jørgensen's (1954) definition of this border, this final stage seems to have set in, roughly speaking. The general forest succession temporarily came to an end, and only local changes gave rise to new successions of a minor order. Thus hazel may have appeared as a pioneer when trees or groups of trees decayed.

If it is true that the forest in the Pre-boreal and Boreal periods is not a clear expression of the climate owing to incomplete immigration of the warmth-demanding tree species, we cannot off-hand attach any climatic significance to the zone transitions IV/V, V/VI and VI/VII; nor can we assume that the zone borders are synchronous over great distances either ${ }^{8}$ ). There may indeed have been some notable climatic oscillations that have not been reflected in the pollen curves. Climatic indicators must be sought for in other organisms, e.g. the aquatics; these plants spread much more rapidly than the trees. At present all we can say is that the temperature conditions were favourable in the zones V and VI; and even optimal in the zone VI since the frequent occurrence of mistletoe (Viscum album), ivy (Hedera helix) and tortoise (Emys orbicularis) (Iversen, 1944, Degerbøl \& Krog, 1951) proves that the summer temperature was considerably higher than today. The frequency of ivy indicates a higher winter temperature, too. Similar conditions persisted throughout zone VII, and one may conclude that the climax vegetation did not change in the zones VI and VII, the Atlantic time. 


\section{The Atlantic Climax Forest}

What was the composition of the primeval climax forest like? The most important tree species were lime (Tilia cordata), elm (Ulmus) and oak (Quercus), but, as it has been mentioned already, lime and elm had the advantage over oak that they are shade tolerant, and a mature oak stand will - on rich soils at least-have an underwood of hazel and suppressed shade tolerant trees which will prevent its regeneration. Normally, therefore, lime and elm would be expected to supplant oak. However, the edaphic requirements of the tree species must be taken into account too. Elm is thus very exacting and occurs on the rich soils only. Lime is less particular, but, contrary to oak and beech, it does not thrive on very poor soils (podsols). Under natural conditions we should, accordingly, in the absence of beech, expect the tree species to be distributed as follows: Tilia forest on the high ground, mixed with Ulmus on rich soil, and with Quercus on poor soil. Only on the poorest soils in Jutland oak has presumably been prevalent. We have two, ecologically entirely different, oak species, Quercus petraea and Q. robur. Quercus petraea prefers high and well drained sandy soils (and acid rocks), and it was no doubt this species that prevailed on the sandhills of Central Jutland, where the species still occurs in small pure stands or scattered in forests of Fagus or Quercus robur. It is not easy to deduce the natural habitat of $Q$. robur from the present distribution because man's activities have for thousands of years favoured Quercus robur at the expense of lime and elm. Judging from the successions in the forests of western Europe we may assume that the species had its original habitats on moist clay and on low-lying ground, even on peaty soil, provided that the peat layer was thin and the ground was not too wet ${ }^{9}$ ). Such an assumption would explain the abundant occurrence of leaves of Quercus robur in mires, a fact that caused STEENSTRUP to introduce the oak period in addition to the pine and alder periods. After the introduction of pollen analysis we have been speaking of the mixed-oak forest period; however, ecological reasoning, as just mentioned, suggests the predominance of Tilia on high ground--until man intervened $\left.{ }^{10}\right)$.

This assumption is in fact supported by the pollen spectra. In the early part of zone VII we find about the same pollen-frequency for Tilia, Ulmus and Quercus; however, since Tilia is insect-pollinated and has thus a poor pollen dispersal, we may conclude that the species was far more widely distributed than indicated by the pollen percentages. This appears indeed quite clearly from our analyses in the Draved forest, where modern samples taken at a short distance from large Tilia stands contain very little Tilia pollen cp. table 1 , no. 1 , and note ${ }^{11}$ ).

Local hydroseres may also influence the pollen diagrams so much that the composition of the climax forest is not discernible. To obtain a clear picture of the forest development on the high ground it will be necessary to look for pools lying in deep 
holes, the sides of which are too steep to leave space for any marginal carr forest. To eliminate the error due to the poor lateral pollen dispersal of the insect-pollinated tree species, the lake or the bog would have to be so small that the tree crowns almost canopy the hole.

These requirements are met with at a tiny 6.5 meters deep bog situated in a beautiful kettle hole, "Hertugdalen", in Gribskov. A boring has been undertaken here in October 1959 by the Geological Survey of Denmark with the objective of checking our assumption that lime was predominant on the high ground in the Atlantic forest. Initial pollen analyses from this series indeed demonstrate a strong preponderance of Tilia in the analyses from zone VII ${ }^{12}$ ). This suggests that the pool was surrounded by Tilia forest in Atlantic time.

However, in low-lying mineral soils (gley-soils, or meadow soils) conditions were different. On one hand, these soils are particularly fertile because there has been no leaching, hence ash and elm, the most exacting species, thrive here. On the other hand, the high ground-water table reduces the competitive power of the shade tolerant trees, especially that of Tilia (not to mention Fagus); this gives a chance to species that demand more light, such as ash and oak. As a result we get a very mixed forest of Quercus robur, Fraxinus excelsior, Ulmus, Tilia, and Alnus glutinosa ${ }^{13}$ ). With a still higher ground-water level the mixed forest will be superseded by an alder (Alnus glutinosa) carr, provided that the water is not completely stagnant.

Throughout zone VII the pollen curves have a very even course, the time of great change is over. The Quercus curve alone differs with its rise in one or two steps. A possible explanation of this Quercus rise, indeed the most natural one, is the filling in of lakes and drying up of bogs. In this way new areas would have become wooded, and forest of Quercus robur would have formed the final stage of the succession here, for purely edaphic reasons. Neither Tilia nor Ulmus thrive in a peaty soil.

A succession like this is directly reflected in the pollen diagrams of peat deposits adjacent to lakes etc. An example of this is given in fig. 1, which shows a pollen diagram from the large bog Lundergård Mose in northern Jutland. Great areas of brackish water from the Littorina time in that region were gradually dried up as the result of regression of the sea in Sub-boreal time. Later this area became a raised bog. However, at the bottom of the bog a layer of oak stools mixed with alder and birch is found; this "buried forest" was uncovered when the peat was flushed away.

The pollen diagram shows how the succession began with Phragmites invading the level, sandy marginal areas of the basin. Next alder immigrated, soon followed by oak (Quercus robur) and a little hazel. Oak forced the alder back; the result was an oak forest mixed with some alder and a little lime. Two generations of thick oak trees were observed, proving that the oak forest existed for at least a few centuries. In the course of this period, however, the edaphic conditions deteriorated owing to peat formation, Tilia disappeared entirely, and alder was displaced by birch. Then, rather suddenly, the forest succumbed and was succeeded by birch scrub, which in its turn developed into a Sphagnum bog with Calluna. So succession began as a progressive "hydrosere" conditioned by decreasing soil moisture, leading to a kind of climax, represented by the oak forest. The subsequent retrogressive succession is presumably conditioned by the change to the cool and moist Sub-atlantic climate. While in Boreal and Atlantic time retrogressive successions occurred only exceptionally, progressive hydroseres were of great importance; in this way oak forest may have developed quite normally. 


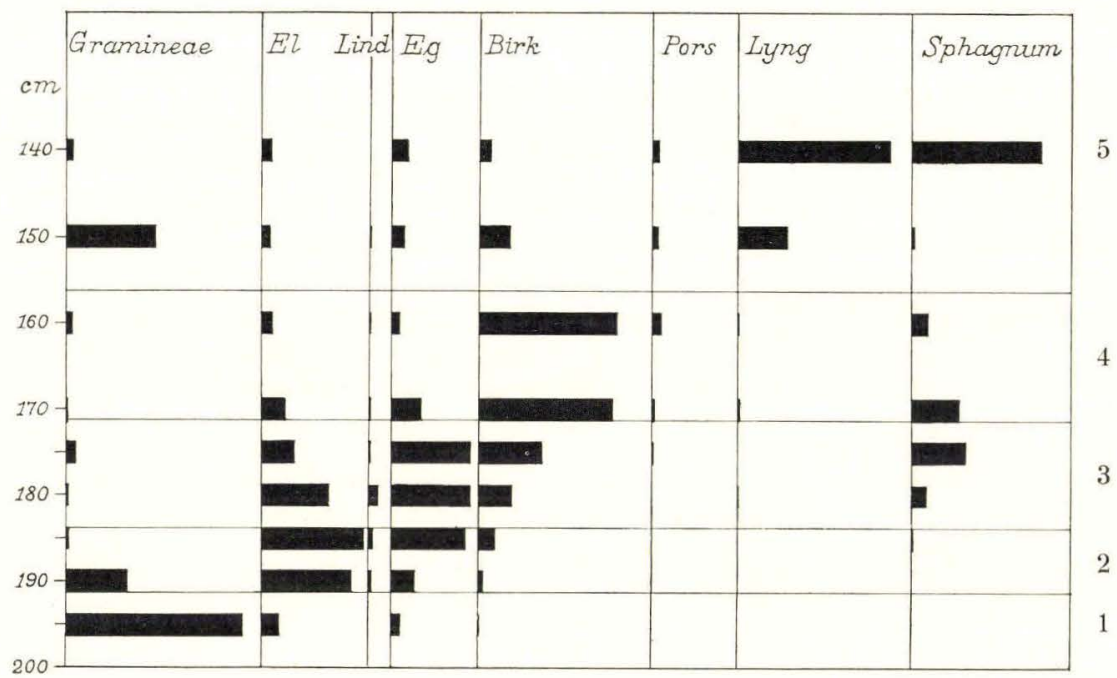

Fig. 1. Pollen diagram from the buried forest in the bog Lundergaard Mose, N-Jutland, showing three stages of progressive succession (1-3) and two stages of retrogressive succession (4-5). From left to right: Gramineae, Alnus, Tilia, Quercus, Betula, Myrica, Calluna, Sphagnum. The hazel curve not included.

Stage 1: Phragmites reed. The diagram does not embrace the pollen of chenopods, which is common; it indicates brackish water conditions.

Stage 2: Alder carr. Immigration of oak (Quercus robur). Lysimachia vulgaris, Dryopteris.

Stage 3: Oak forest. Immigration of birch.

Stage 4: Birch shrub. Myrica gale (= Pors). Frangula, Lysimachia vulgaris, Assulina, Arcella, etc.

Stage 5: Sphagnum-Calluna raised bog. Drosera rotundifolia.

This explanation of the rise of the Quercus curve is supported by a close study of the correlation between the various pollen curves. Thus, in Atlantic time, there is a clear negative correlation between the pollen curve for oak on one hand, and the curves for the other tree species that take part in hydroseres (Alnus and Betula) on the other hand, while no such correlation exists with Tilia and Ulmus.

The rise in stages of the Quercus curve may thus be explained without assuming any changes in the composition of the forest on the high ground. Again, this interpretation may not include all factors. In Post-glacial time weathering and leaching resulted in a gradual, but very slow change of the soil. In the first stages of forest development these processes led to increasing soil fertility; indeed, the fertile mull was formed through this soil maturing. On poor sandy soils, however, the leaching may eventually have resulted in soil degradation which would affect the balance between elm, lime and oak in favour of the oak.

Such an edaphically conditioned retrogressive succession on high ground has been proved to exist in the Sub-boreal period and later. In Draved forest, on low banks of dune sand, we may find a layer of purely organic acid humus, a kind of oak-mor, up to $50 \mathrm{~cm}$. thick. The lower part of this layer is so strongly decomposed that it consists chiefly of well preserved pollen grains, in addition to the pure humus. Between this mor-layer and the underlying bleached sand, which contains almost no pollen, 
we find a dark mull-like sand horizon very rich in pollen. The pollen in this stratum dates from a time when soil deterioration had already produced very low $\mathrm{pH}$ values, otherwise the pollen grains would have disappeared as a result of bacterial activity. Hence the pollen flora reflects the tree growth at an intermediate stage between brown forest soil and podsol ("grey-brown, podsolic soil"). The analyses (table 1, no. 7) show that at this stage the forest was a mixture of oak, lime, and hazel. In the mor, lime and hazel disappear, and oak becomes predominant (no. 6-4). Hence, we have an example of a change in composition of the forest owing to soil degradation in Sub-boreal time ${ }^{14}$ ). The initial stage of the succession, the forest of the mull soil, cannot be studied in these profiles, but we may assume that lime predominated. At any rate, in the following stages oak advances at the expense of lime. In a similar way deterioration of the poor sandy soils may already in Atlantic time have led to a rise in the frequency of oak.

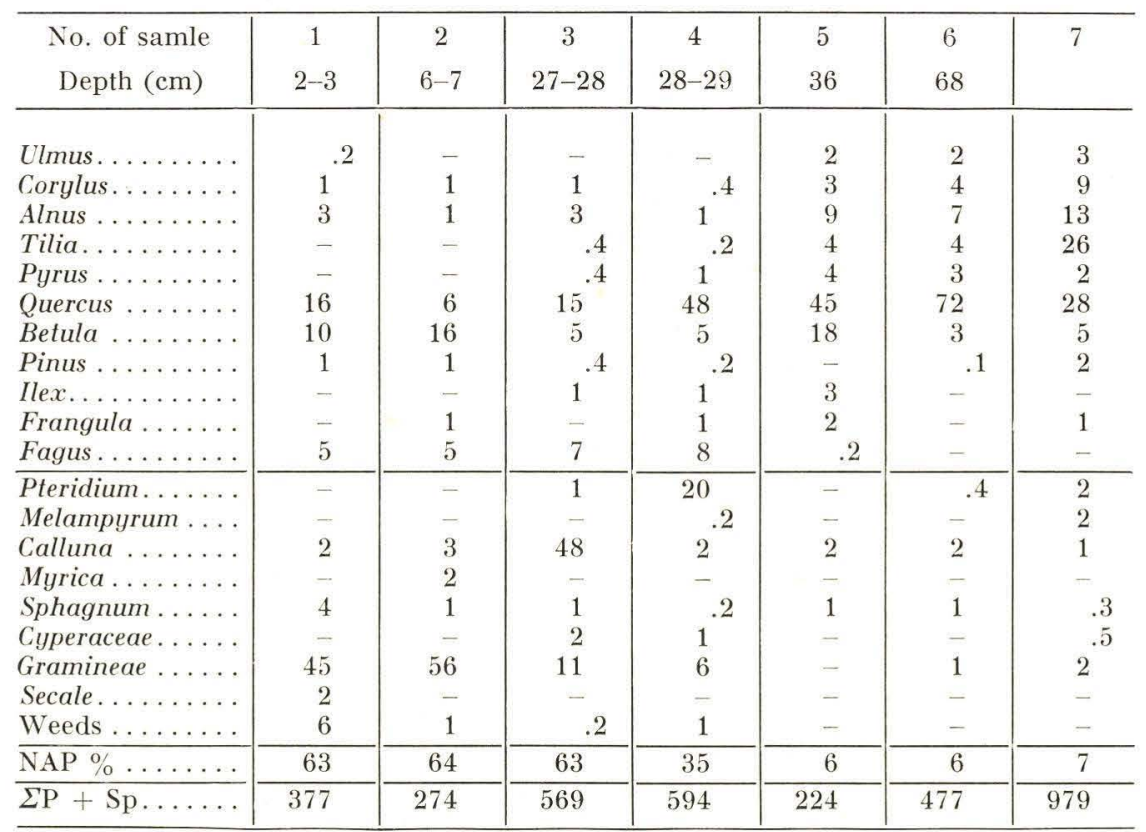

Table 1. Pollenanalyses from two podsol-profiles in Draved forest.

No. 1-6. Section $60 \mathrm{~m}$ east of a large natural stand of Tilia (about 500 trees). Until recently a local vegetation of birch scrub with Molinia, to-day a young plantation of Picea sitchensis. Local stratigraphy: 0-6 $\mathrm{cm}$ : Picea-rawhumus; 6-8 cm: MoliniaBetula peat; $8-28 \mathrm{~cm}$ : Calluna-rawhumus; $28-68 \mathrm{~cm}$ : Quercus-mor, highly humified; $>68 \mathrm{~cm}$ : strongly podsolized dune sand. $\mathrm{C}_{1^{-}}$-date of sample no. 5 is 50 A.C. \pm 100 . No. 7. Mull horizon in bleached sand from another podsol profile in Draved forest, $6 \mathrm{~cm}$ beneath the mor-layer. Some pollen grains with signs of corrosion.

The pollen counts of Alnus, Betula, Pinus, Corylus, and Calluna are divided by 4 prior to calculation of percentages. Scattered occurrences of Fraxinus, Salix, Hedera (no. 4 \& 7 ), Viscum (no. 7), Picea (no. 1). 


\section{The Ulmus fall and the first appearance of farming}

The smoothness of the pollen curves during Atlantic time contrasts sharply with the choppy changes in all curves of the Sub-boreal period. A new, decisive factor appears, man's influence on the forest. From now on all interpretation must include human interference.

Fortunately, the important weeds and many cultivated plants are wind-pollinated and disseminate pollen in abundance. The correlation between certain tree pollen curves and the curves for the various species of weeds and cereals enables us to throw light upon the cultural influences on forest development in great detail (fig. 2-4). In the remarkable landnam phases from the early Sub-boreal this correlation is so striking that the interpretation of the curves as denoting successions following extensive forest clearings (Iversen, 1941) seems to have been generally accepted.

The interpretation of the first distinct decline in the Ulmus curve, the "Ulmus fall":), which set in some time before the landnam phase, is, however, controversial. A brief account of the two opposite interpretations at hand will follow here.

The first interpretation (Iversen, 1941) is based on the observation that the pollenfrequency of ivy (Hedera) shows a very marked decline concurrently with the Ulmus fall. Ivy is a very sensitive climatic indicator, and its marked decline at the transition from Atlantic to Sub-boreal time suggests a climatic change, which might then have resulted in the contemporary "Ulmus fall" too, since some species of the latter (particularly Ulmus carpinifolia) are distinctly thermophilous. At about this time ash (Fraxinus excelsior) progresses, and in the Sub-horeal zone it may be said to take the place of elm in the pollen diagrams. This, too, may be explained by a climatic change, on the hypothesis that ash may replace Ulmus carpinifolia on a moist, fertile soil.

The second interpretation (F FGRI, 1944, Troels-SmITH, 1954, 1955) is that the Ulmus fall is culturally conditioned, and the reasons are these: Ulmus is the most highly rated "fodder tree", the foliage of which was used from times immemorial for stall-feeding of the cattle (cf. for instance NoRDHAGEN, 1954). For this purpose the trees are pollarded and their twigs lopped every few years. Such a treatment will prevent the elm from flowering, and the declining pollen frequency of the genus may thus be due to this type of animal husbandry. Troels-Smith has subsequently (1960) further applied a similar interpretation to the contemporary decline of Hedera, the evergreen foliage of which is used as winter fodder even today.

This interpretation of the Ulmus fall is sustained by the fact that pollen of cereals and plantain are traceable in minute quantities already before the forest clearing phases, but never before the Ulmus fall. The same applies to ramson (Allium ursinum), which may

*) In the following the designation "Ulmus fall" means the first elm decline, which signifies the zone boundary VII-VIII, contrary to later declines. 


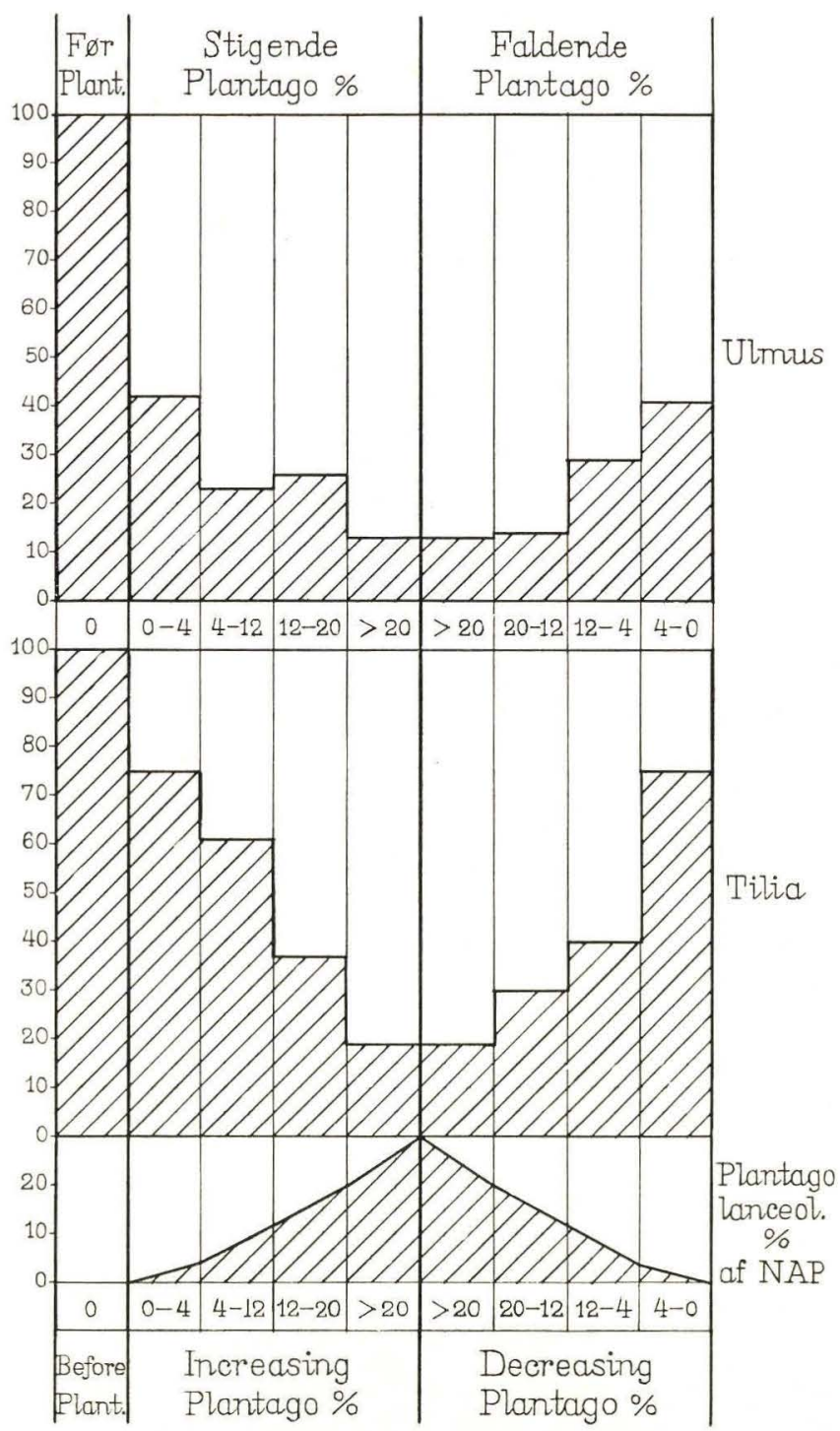

Fig. 2. Correlation between pollen frequency of Plantago lanceolata (indicator of pasture land) and that of elm (Ulmus) and lime (Tilia) in pollen diagrams covering the early stages of Neolithic farming culture in Denmark.

The analyses in each diagram are grouped according to increasing, culminating and decreasing pollen frequency of Plantago lanceolata. Further explanation see note 15. It appears from the figures that the frequency of elm and lime was highest in the virgin forest, the effect of farming culture was destructive to both. When later the forest recovered they did not regain the original frequency. 


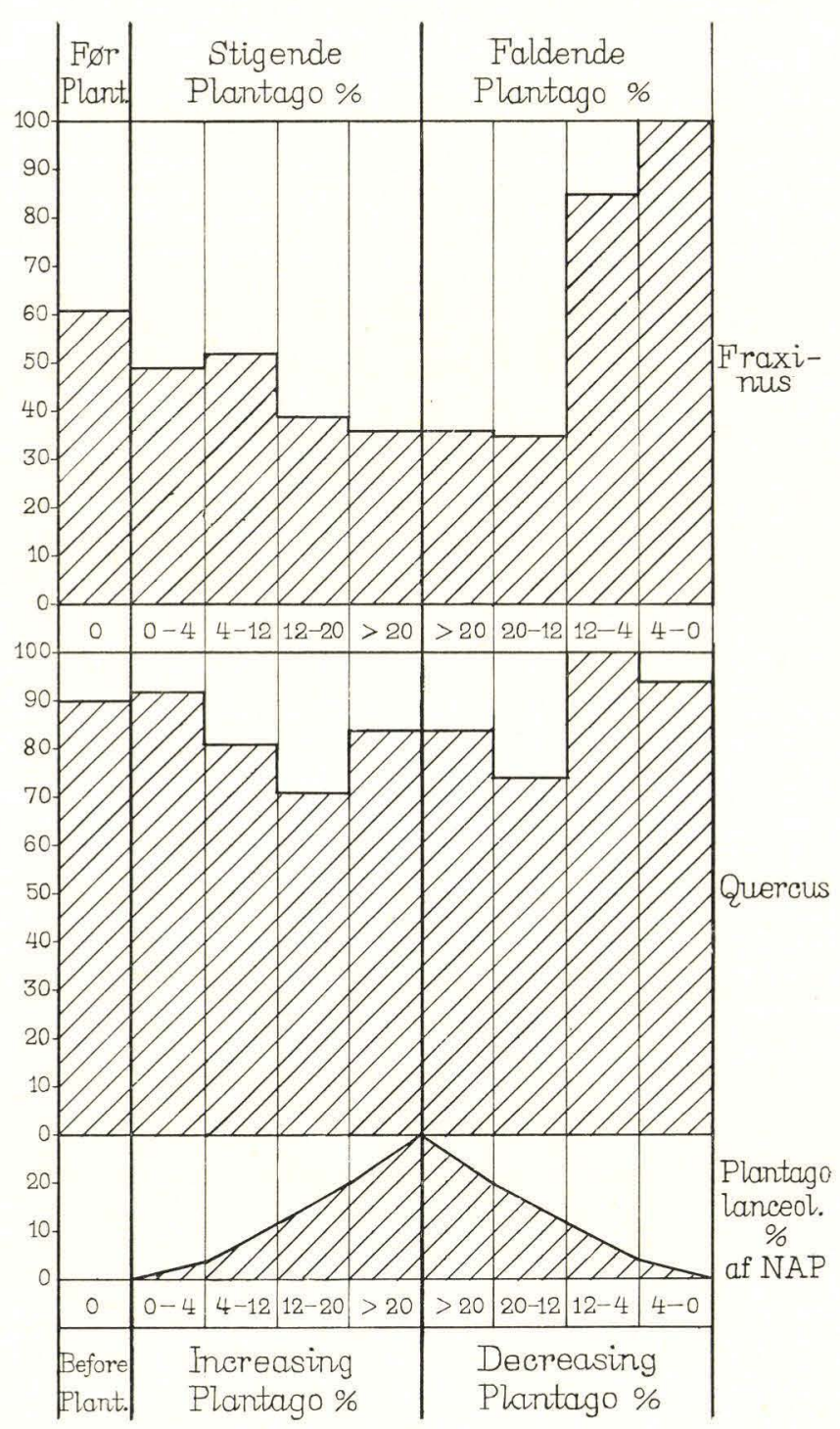

Fig. 3. Correlation between pollen frequency of Plantago lanceolata (indicator of pasture land) and that of ash (Fraxinus) and oak (Quercus) in pollen diagrams covering the early stages of Neolithic farming culture in Denmark, (compare Fig. 2).

It appears that the pollen frequency of ash and oak is but slightly influenced by the farming activities, except that ash achieves much higher pollen frequency after regeneration of the forest than before the clearing. 


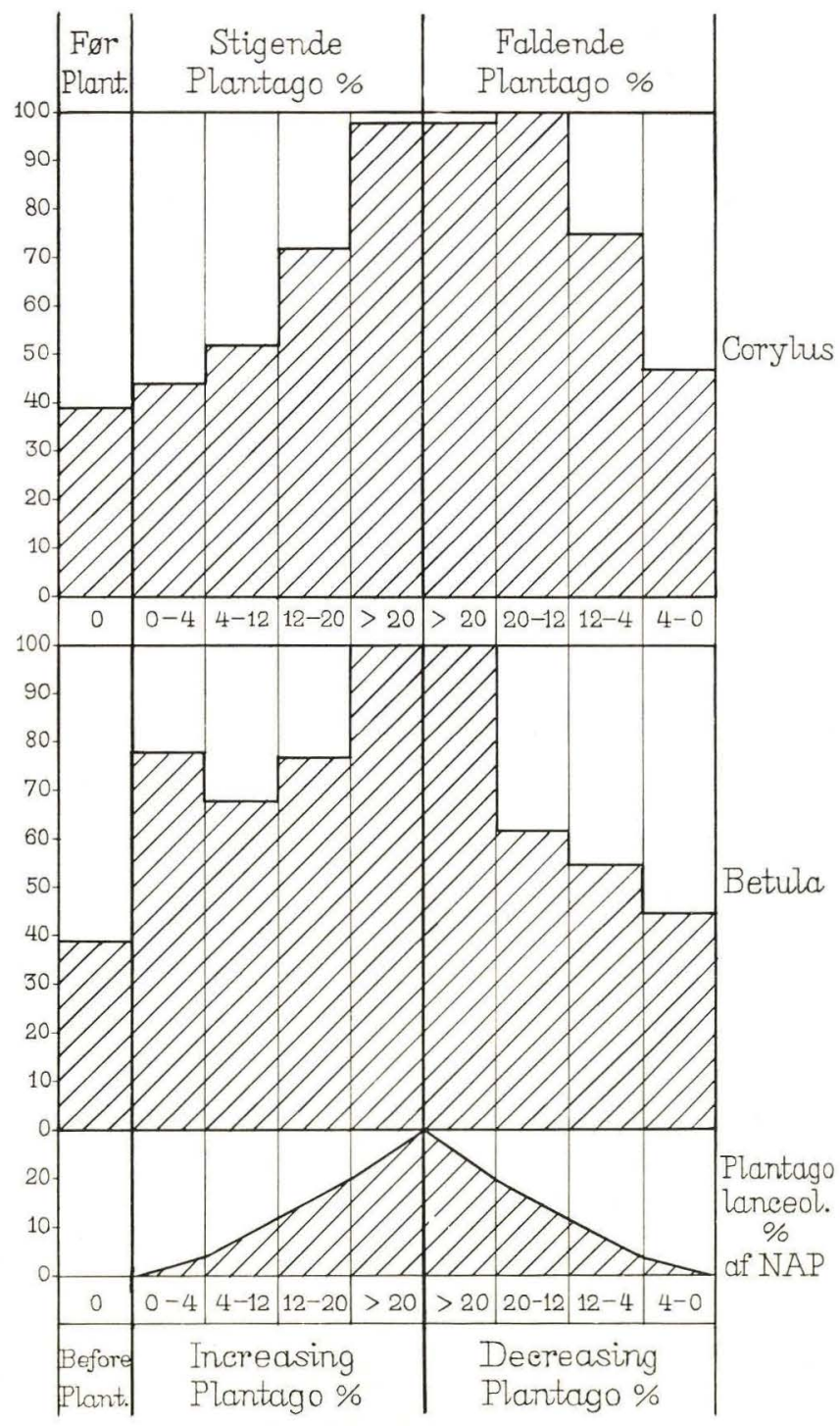

Fig. 4. Correlation between pollen frequency of Plantago lanceolata (indicalor of pasture land) and that of hazel (Corylus) and birch (Betula) in pollen diagrams covering the early stages of Neolithic farming culture in Denmark (compare fig. 2).

It appears that birch and hazel were favoured by the farming activities, and were repressed when later the forest recovered. 
likewise be regarded anthropochorous. On the strength of their extensive investigations, Trofis-SMith and his collaborators have been able to link up the diagram section in question, which contains faint traces of pollen from weeds and cereals, with a definite archaeological milieu that is characterized by Becker's A-ceramics (Becker, 1948). According to Troels-Smith this A-culture is identical with the "Classical Ertebølle Culture", which was not simply a hunter's and fisherman's culture, but a primitive semi-agriculture. Troels-Smiтh (1954) envisages these very primitive farmers with small grain-fields, while their cattle were stalled all the year round, i. e. their animal husbandry was based entirely on foliage used as fodder. This form of farming would thus be in contrast with the somewhat later Landnam Culture, characterized by pasturing cattle in large numbers, a fact which appears clearly from the great pollen frequency of grasses and Plantago lanceolata (Iversen, 1941). Troels-Smith (1954) concludes that indeed they represent two fundamentally distinct cultures. Recent pollenstatistical contributions to these questions have been given by Franks 1957, Florin 1957, Hafsten 1957, Smith 1958, Fries 1958, Waterbolk 1958, van Zeist 1958, Morrison 1959.

We shall now, once again, try to assess the distinctive changes in the pollen curves at the transition from the Atlantic to the Sub-boreal zone in the light of the ecology and sociology of the tree species.

The first pollen curve to be considered is that of ash (Fraxinus). Though ash immegrated already in Boreal time, the pollen of the genus is scarce for a long time. However, at the end of the Atlantic Zone Fraxinus has a marked rise.

As mentioned, ash has an intermediate position between a pioneer species and a climax species: its reproduction rate is superior to that of a climax species, but it is not quite so competitive, because it has rather high light requirements and a rather short life. Ash demands a rich soil and normally it grows only where the water table is rather high; on the other hand, contrary to alder (Alnus glutinosa), it does not tolerate a saturated soil. On high ground it may temporarily appear as a pioneer tree after a clearing.

A close study of the pollen diagrams will show that the sharp Fraxinus rise at the end of the Atlantic Zone is compensated for by a corresponding decline of the Alnus curve, whereas Quercus usually increases too. Tilia decreases somewhat. Ulmus and Betula reveal no clear reaction. The marked recedence of Alnus demonstrates that Fraxinus must have spread at the expense of Alnus, i. e. on moist ground. This is explained most easily if we assume a lowering of the ground-water level. This change would at first favour ash, which owing to its high reproduction rate spreads faster than the other trees of the mixed forest in the formerly wet, and now partially dry alder zone. Likewise Quercus robur can increase its area, whereas there is no reason to assume a rapid change in the composition of the forest on the slightly higher ground whence ash and oak proceeded, i. e. the damp mixed forest. Ash and particularly oak will withstand a sudden lowering of the ground-water level, though lime may eventually become stronger in competition because its flat root system now develops into deeper soil too. A lowering of the water table will be due to a warm and dry climate, which is consistent with the relative high pollen frequency of Viscum and Hedera at this time.

Though the advance of Fraxinus, as we have seen, may easily be explained climatically, we cannot quite disregard the possibility that it may have been the result of man's earliest interference. So far, however, this possibility has not been supported in any way.

An interpretation of the Ulmus fall is made difficult by the fact that it has, so far, not been possible to distinguish the various Ulmus species by their pollen 
grains. The Ulmus curve in Atlantic time may have included Ulmus montana, $U$. carpinifolia and $U$. effusa. Ecologically the species mentioned do not differ greatly, all three usually grow in rich, rather moist soil; Ulmus carpinifolia and $U$. effusa prefer, however, a high water-table to a larger extent than $U$. montana. The warmthdemanding $U$. carpinifolia thus grows on a soil similar to that of Fraxinus.

The changes of the pollen composition at the zone boundary VII/VIII are quite characteristic. Two features are basic for the ecological evaluation of the Ulmus fall.

In the first place: In most pollen diagrams the sharp decline of the Ulmus curve is offset solely by a rise of the Quercus curve. As the latter is very clearly marked and often exceeds the decline of the Ulmus curve, we must presume an actual increase in the production of oak pollen. Accordingly oak must have benefited from the decline of elm, i. e. it must have grown side by side with elm. As explained above, we must assume that oak had two entirely separate habitats, viz. the dry sandy soil (Quercus petraea) and the low-lying moist ground (Q. robur). It is inconceivable that elm can have grown side by side with Quercus petraea. On the other hand, as already mentioned, we must assume that Quercus robur formed a mixed forest together with elm, lime, ash and alder on rich mineral "gley" soils, for instance near water courses and lakes. Hence, it is indicated clearly that the Ulmus fall was due to changes in this moist mixed forest. In the case of the poor sandy regions of Jutland this is a foregone conclusion, because elm and ash could not possibly have grown elsewhere.

In the second place: Fraxinus recedes together with Ulmus in many of the diagrams. If the warmth-demanding Ulmus carpinifolia was killed by winter cold, we would expect a consistent advance of ash, which grows on the same type of soil and would have received improved light conditions. So, while the climatic interpretation of the Ulmus fall might very conveniently explain the broad features: replacement of Ulmus by Fraxinus in Zone VIII, it fails when we go into details. The recession of Fraxinus is, on the other hand, quite consistent with Troess-Smith's interpretation since the foliage of ash, like that of elm, is regarded to be optimal for fodder.

The difficulty in Troels-Smith's interpretation is only quantitative. It is always the same hesitation that is advanced: Is it really possible that the number of flowering elms in a region could be reduced to such an extent and in such a short time only because of the use of their foliage for fodder? Again, is it possible in this way to explain the fact that the Ulmus fall is found fairly synchronously throughout the country? Below we shall consider these questions in the light of forest-ecology.

In the current international discussion on the Ulmus fall and the use of foliage for fodder it seems to have been taken for granted, so far, that the theory embraces pollarding of elms interspersed in the mixed-oak forest. To explain the sharp decline in the Ulmus curve such a pollarding must have included a very large number of elms. This would be so great a task that most people interested in the question find it difficult to visualize a very primitive people of the stone age undertaking it. Actually it seems unlikely that such a pollarding of tall mature elms would serve any purpose. The people would have had to climb 15 metres or more up the trunk to reach the branches. To-day pollarding begins before the trees grow to any considerable height, and the same applied no doubt in the stone age.

As stated above, ecological reasoning leads us to conclude that the elm trees involved in the Ulmus fall grew in a mixed forest on the rich gley soils. This is very reasonable, for it is only here that ash and elm, the trees that grow the best fodder, form a major proportion of the forest and, consequently, of the regeneration too. 
Hence, by killing a considerable part of the mature trees ideal conditions for picking the foliage would be created. No felling was necessary, the trees could have been killed easily by girdling, as done until recently, e. g. in the Balkans, and it would have been possible subsequently to prune the young elms, ashes, etc., of the resultant regeneration. By sparing the oak trees when girdling another advantage would have been obtained. The acorns were of supreme importance as food for livestock, and for man too, throughout antiquity and later (cf., e. g., Brockmann Jerosch, 1936). When growing as standards in a low forest the fertility of oaks will increase greatly. The steepness of the Ulmus fall supports the explanation given above; a slower decline was to be expected if the elm fall was due to pollarding in itself. On the other hand, pruning of the young trees would explain the fact that the Ulmus curve-in contrast to the Fraxinus curve-does not rise again. As stressed by several authors, pollarding prevents elm, but usually not ash, from flowering (see e. g. Nordhagen 1954).

According to Troels-Smith, the people of "classical Ertebolle culture" were responsible for the Ulmus fall, and he has pointed out that the discoid axes, the typical implements of this culture, are well suited to barkpeeling. With these axes the Ertebølle people could easily, and in a short time, have converted considerable areas of moist mixed forest into coppice, suited to the picking of foliage.

With practically no knowledge of the details of this prehistoric farming we must content ourselves with analogisms from primitive farming as practised in historical time. According to Troels-Smith's theory the domestic animals had presumably been tethered, or kept in a stall (or paddock) where they were fed with foliage. We may, however, assume that during the warm time of the year the goats, and perhaps the cows too, browsed in the coppice produced through cultural interference. In the mountains at Amalfi, S. Italy, where I have had opportunity to study this type of farming, the goats browsed freely in the scrubs watched by a goat herd, whereas the cows were stall-fed. It should be noted, however, that this steep rugged mountain landscape is unsuited to cattle browsing. 


\section{Ivy (Hedera helix), Holly (Ilex aquifolium) and Mistletoe (Viscum album) in Atlantic and Sub-boreal times}

As mentioned above, ivy and mistletoe are our best indicators of climatic conditions, ivy especially of winter, and mistletoe of summer temperature. The high pollen frequencies of these species in zones VI and VII indicate that the winter and summer temperatures were substantially higher than those of today. Since a detailed discussion on this subject appeared in a previous paper (Iversen, 1944) we shall here only consider the facts that have emerged since then, and which have changed or sharpened the problems.

The first point to be considered is the effect of cultural intervention on the ivy curve. I have previously (1949, p. 16) pointed out that the landnam clearances were detrimental to ivy, which may, however, have regenerated fairly soon. Yet, the first sharp fall in the curve of the species occurs already simultaneously with the Ulmus fall. Our inference of a climatic depression at the zone border VII-VIII was indeed based on this fact. After Troels-Smith has demonstrated that the Ulmus fall is probably culturally conditioned, the question arises as to whether the decline of ivy (and of mistletoe) ${ }^{16}$ ) may also have been caused entirely by cultural intervention. Since the arguments in support of the latter assumption will be competently dealt with by Troels-Smith (1960), I shall confine myself to giving a few facts indicating that climatic conditions too have contributed to the decline of ivy in the Sub-boreal period.

For my earlier discussion (1944) Danish material only was available, but since then a large material has been published in our neighbouring countries (JESSEN, 1949; Godwin, 1956; HAFsten, 1957 and others), while the Danish material has increased substantially (e. g. MrkкELsen, 1949). Fig. 5 is based on this material and shows the average frequency of Hedera in zones VII and VIII in various areas. Several interesting features may be deduced from the figure, and they provide clear evidence as to the influence of climatic factors on the frequency of flowering ivy in Atlantic and Sub-boreal time.

1. Though ivy, flowering in tree crowns, is very scarce in Denmark today, it was as common along our coasts in Atlantic time, as it was in England and Ireland.

2. Ivy was not nearly so common in the interior of Jutland where the temperature was a little lower.

3. The Sub-boreal decline in the Hedera pollen curve is very pronounced in 
northern Denmark, which is a region of isostatic elevation. The decline is, on the other hand, very slight in south-western Jutland and at the southern North Sea coast (Grohne, 1957; van Zeist, 1959), a region of local down-warping (subsidence).

4. In extremely oceanic regions (Ireland) Hedera is found not to recede at all in Sub-boreal time, contrary to Ulmus.

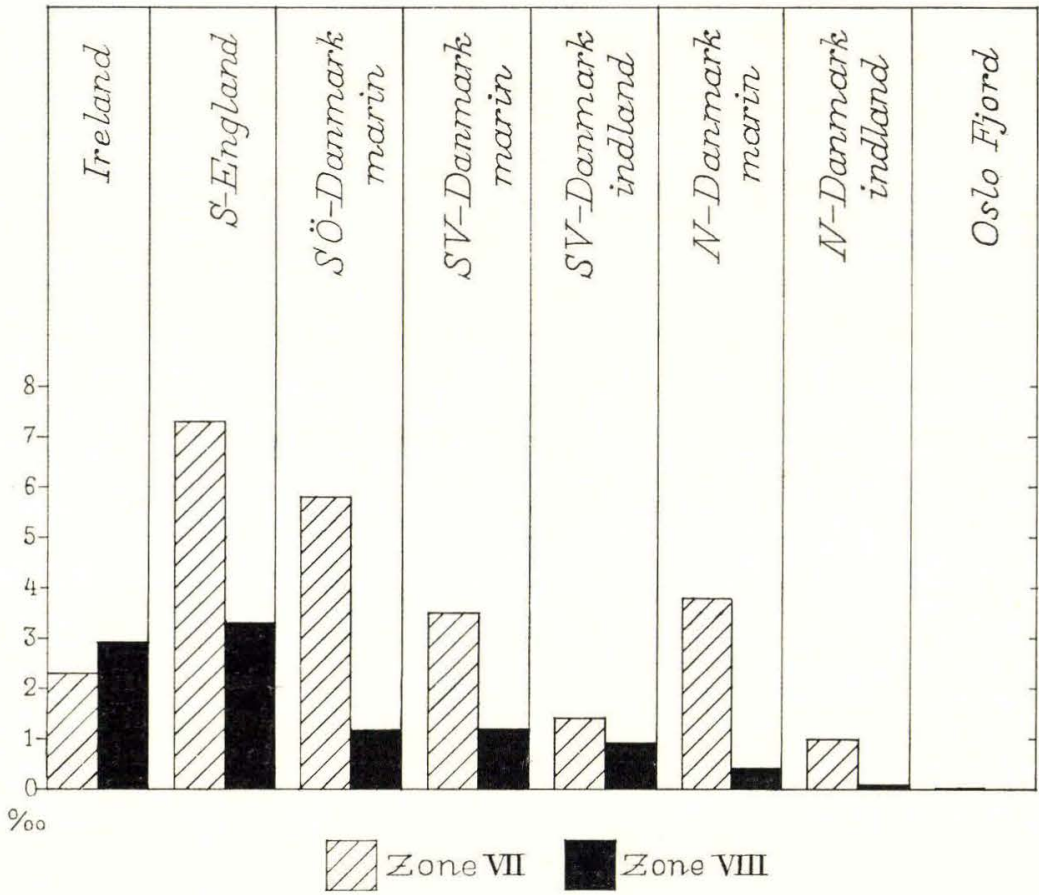

Fig. 5. Pollen frequency of ivy (Hedera helix) in zone VII and VIII, respectively, in various regions. The basis of calculation is the total of tree pollen (without Corylus). The great frequency of Hedera pollen in Danish marine deposits from Atlantic time is clearly indicated as well as the sharp decline in Sub-boreal time, especially in northeastern Denmark.

From (1) we may conclude that the climatic conditions at our coasts were optimal to Hedera in Atlantic time. Point (2), on the other hand, shows that winter temperature approached the critical threshold since the rather slight climatic difference between coast and inland had an appreciable influence on Hedera's flowering. Hence, a fairly modest general fall in winter temperature would affect the Hedera curve. A lowering of the winter temperature would be intensified in the north of Denmark on account of the sea's regression, but counteracted in the southern subsidence area on account of the sea's transgression. This is consistent with (3). Finally, also (4) is directly consistent with a climatic interpretation (cf. Fegri, 1940; JeSSEN, 1949); winter temperature in Ireland was and is well above the critical threshold value. Our theory that the Sub-boreal decline of the Hedera curve was due to cold winters is 


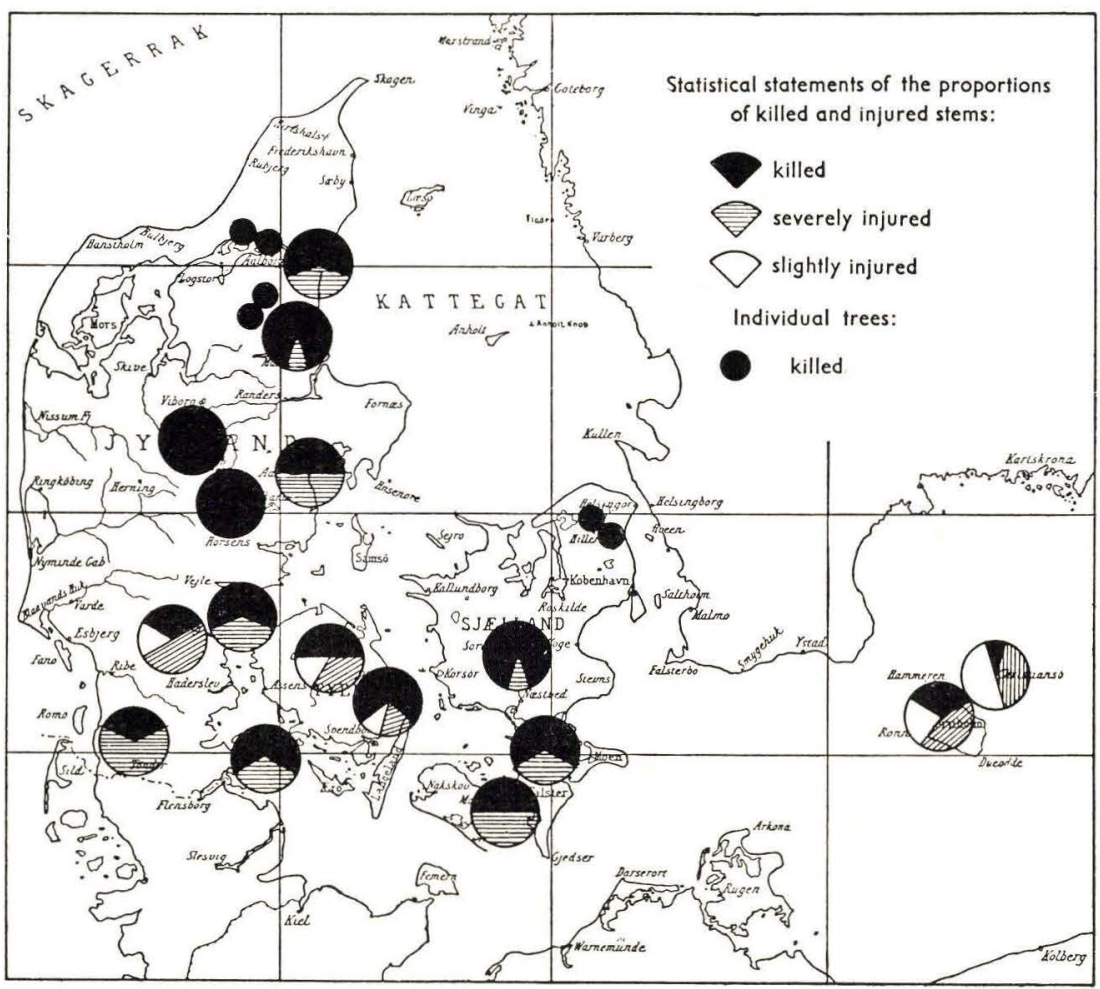

Fig. 6. Effect of the hard winters 1939-42 upon Hedera helix f. arborea. Only climbing stems exceeding 1 inch in thickness included. (IVERSEN 1944).

thus sustained by the four points mentioned above, which have appeared since 1944 . Anyone who has seen how two cold winters (1939/40 and 1941/42) could reduce an entire country's wild flowering ivy to a small fraction of the original population (cf. fig. 6) will not be likely to ignore the importance of this factor.

This is not to say that the Ertebølle people's use of foliage has not influenced the Hedera curve (Troels-Smith, 1960). We may assume that Hedera grew in the moist mixed forest, and the species has no doubt thrived in the coppices. The ivy's green leaves were a valuable food for the livestock in early spring when the winter fodder had come to an end.

It is impossible to apportion climatic and anthropogenic factors in the decline of ivy. We must content ourselves with a subjective opinion, and this may vary among students. The present author regards both factors as important: the transitory depressions in the Hedera curve may frequently be conditioned by culture and of local importance, whereas the falling tendency of the Hedera curve must be due to decline in temperature. The strikingly different behavior of Hedera in, for example, the Danish and the Irish pollen diagrams can be understood only in this way. Really high values of Hedera are found in Denmark in Atlantic time only, and never later on; they are not found between the culture-conditioned depressions either. In 
Ireland, on the contrary, Hedera reaches a higher frequency between these minima than it did in Atlantic time (Sмгтн, 1958).

Holly (Ilex) too must be mentioned in connection with these problems. Pollen grains of Ilex are extremely scarce in Danish deposits; no more than say 12 pollen grains are known from Atlantic time (zones VI and VII). Since the distribution of holly is at least as dependent on a mild winter climate as ivy, one might be tempted to conclude that the winter temperature was too low for Ilex in Atlantic time. However, such a conclusion would be erroneous because Ilex pollen is also extremely rare in Atlantic deposits in southern England, although the climate there was undoubtedly ideal for the species throughout the Post-glacial time. Hence, the almost complete lack of pollen-finds from Atlantic time must have other causes. GoDwin (1949) rightly points out that light conditions in the virgin forest were unfavourable to a small tree like Ilex, and that they had been improved by man's activities in the forest (cf. also VAN ZEIST, 1959).

However, it seems to emerge from our investigations in the Draved forest that this does not provide the whole explanation. In the terrestrial mor-deposits mentioned above Ilex pollen occurs with frequencies of up to a few per cent (see table 1, p. 13), whereas not one pollen grain has been found in the peat of the mires, inside or outside of the forest, although the number of pollen analyses from the mires are many times greater. Consequently, Ilex pollen occurs only in the sediments of the forest itself. This is no doubt due to the fact that at the time of flowering this small tree is covered by a leafy canopy. The result is that its pollen cannot become dispersed into the atmosphere and into the lakes and bogs ${ }^{17}$ ). The chances for such a dispersal will be much greater when the high forest is cleared, and we may in that way explain the fact that more Ilex pollen grains have been found in English bog sediments from above the Atlantic-Sub-boreal zone border than below it. In Danish limnic and marine sediments about the same number of Ilex pollen grains are found in Atlantic and in Sub-boreal time $(11: 11$; cp. Troels-Smith's statement 1960, 3 recent finds (H. Krog, 1960) added. Thus, unlike what was found in England, there is no increase in the pollen frequency of Ilex in Sub-boreal time, despite the thinning of the forest.

There is, in fact one similarity in the Post-glacial pollen distribution of Hedera and Ilex. While in Atlantic deposits the pollen frequencies of both species are approximately the same in Denmark and England, the frequencies are in Sub-boreal deposits much smaller in Denmark than in England. Yet, until much more material is available, it would not be wise to draw any climatic conclusion from the pollen finds of Ilex, except that the winter temperature was not lower than to-day.

The same reasoning applies to Lonicera periclymenum, which is very similar to Hedera (and Ilex) climatically, but corresponds to Ilex as to pollen dispersal.

\begin{tabular}{|c|c|c|c|c|c|}
\hline & $\begin{array}{c}\text { Ireland } \\
(\text { JESSEN, } \\
1949)\end{array}$ & $\begin{array}{c}\text { S } \\
\text { England } \\
\text { (Gonwis, } \\
1949)\end{array}$ & Denmark & \begin{tabular}{|c|} 
Oslo \\
region \\
(HAFSTEN \\
$1956)$
\end{tabular} & $\begin{array}{c}\text { Middle- } \\
\text { Sweden } \\
\text { (FLORIN, } \\
\text { 1958) }\end{array}$ \\
\hline$\frac{\text { Viscum }}{\text { Viscum }+ \text { Hedera }} \times 100 \ldots \ldots$ & 0 & $<1$ & 16 & 95 & 100 \\
\hline
\end{tabular}

Table 2. The ratio of Viscum pollen to Viscum + Hedera pollen in the Postglacial warm period in various districts. 
Pollen of Lonicera periclymenum is frequent in Draved's terrestric mor layers too, and only a few pollen grains have been found elsewhere in Denmark in Post-glacial sediments from very small basins.

Compared with the distribution of Hedera (and Ilex) that of mistletoe (Viscum album) is more continental in character. This also appears from the relative pollen frequency of Viscum and Hedera in sediments from the Post-glacial warm period. In Ireland only Hedera pollen is found, in Södermanland (south of Stockholm) only Viscum pollen, and between these extremes the relative pollen trequency of Hedera and Viscum changes gradually (see table 1). Thus a rising Viscum: Hedera ratio may indicate a change in the direction of continental climate, while a decline in the Viscum: Hedera ratio may manifest an increase of oceanity. Provided that this conclusion is correct, table 2 indicates that the climate of south-western Jutland and the Netherlands (region of isostatic transgression of the sea) was slightly more oceanic in zone VIII than in zone VII, while the opposite was true in N E Denmark (region of isostatic regression of the sea) ${ }^{18}$ ).

\begin{tabular}{|c|c|c|}
\hline$\frac{\text { Viscum }}{\text { Viscum }+ \text { Hedera }} \times 100$ & Zone VII & Zone VIII \\
\hline N E Denmark: isotatic rise since Littorina-max $>3 \mathrm{~m} \ldots$ & 14 & 26 \\
\hline Denmark: isostatic rise since Littorina-max $0-3 \mathrm{~m} \ldots \ldots$ & 15 & 16 \\
\hline S V Denmark: transgression continued since Littorina time. & 19 & 11 \\
\hline Netherlands, S E Drenthe: (v. zEIST, 1959). & 21 & 12 \\
\hline
\end{tabular}

Table 3. The ratio of Viscum pollen to Viscum + Hedera pollen in the zones VII and VIII in areas of regression and transgression respectively.

The length of the interval occurring between the Ulmus fall and the great forest clearings, designated as "landnam", varies, and in a few pollen diagrams no such interval is found at all. In the latter cases there is, of course, a decline in the elm curve, but this fall is linked with a typical landnam, which always greatly affects elm. The diagram from Sækkedammen (fig. 5 in Iversen, 1949) is an example. If we accept Troess-Smith's conception, we may assume that the Ertebølle people never had any settlement near that lake. Similar conditions might be found at many places, no doubt, if we had more sufficiently detailed diagrams from such small inland lakes.

On the other hand, we do not know of any single detailed Danish pollen diagram that does not show neolithic forest clearances. Obviously stone age farmers of some culture pattern or other have been practically everywhere in this country, transiently at any rate. This tallies with the fact that no fairly large lake or bog exists near to which polished flint axes have not been found. In the Neolithic age Denmark was presumably one of the most densely populated regions of Europe. In this country it is, therefore, difficult to obtain a clear picture of the climatic development in this phase by means of pollen diagrams because the relevant evidence is obscured by extensive cultural interventions. 


\section{Notes}

1) Abundant evidence has been compiled in the books of Dengler (1935), RubNer (1935), Kirchner, Loew, Schröter (1908 etc.), and Morosow*) (1925).

2) The ideas and the system of CLEMENTs (1916) have stimulated to fruitful research, and also given rise to much sophisticated dispute. The latter may be due to the fact that CLements' terminology was not always kept clear of his theory. A sound modification of Clements' system is presented by TAnsley in his excellent book: "The British Islands and their Vegetation". We feel that TAnstex's conception should be adopted in pollen analysis, which, in its turn, may serve as an inductive method for dynamic plant geography, when properly adapted to this particular purpose. In this way a sound factual basis may be established for the study of succession and the assessment of climax vegetation, and there is no need for resorting to problematic analogisms from vegetational zonations.

Since Neolithic time successions are often greatly modified by human activities ("deflected successions" sensu Godwin, 1929), and even TANSLEy's Climax communities are, no doubt, modified by man. It might perhaps be better to replace the word climax by a more neutral term when dealing with regions or periods where deflected successions prevail (cf. WALTER 1954).

When climate is stable or improving most successions are progressive, while retrogressive successions (Moss) normally occur in response to climatic decline. Soil degradation too may without man's interference bring about retrogressive succession in a climax forest, as suspected by TANSLEy (1. c. p. 26) and clearly demonstrated by pollen analysis (see, e. g. the present paper p. 12). Through retrogressive succession forest may develop into moorland (disclimax), as described by Pearsall (1950).

3) Virgin forest in southeastern Europe.

Careful analyses of the composition and regeneration of the vanishing temperate virgin forests in the mountains of S E Europe between the B]ack Sea and the Adriatic Sea are given by Fröhlich 1930, Mauve 1931, Markgraf und Dengler 1931; see also Rubner (1. c.). As stressed by the authors mentioned those virgin forests are stable communities of shade tolerant tree species (chiefly Fagus silvatica and Abies pectinata). The normal regeneration is said to be in small groups ("gruppen oder kleinhorstenweise" FröHLICH, RUBNer a. o.), and it is stressed that regeneration appears abundantly a few decades prior to the decay of old trees or tree-groups. Suppressed, often more than 100 years old shade trees are said to be of greatest importance for the regeneration of the high forest. Catastrophic destruction of large forest areas are rare exceptions in those virgin forests, accordingly pioneer trees are of very restricted occurrence. Deer is very sparse and without influence on regeneration.

Pollenstatistical evidence demonstrates that the Atlantic virgin forest in Denmark was of a similar stable type (climax forest). However, in conifer regions and where the climate is arid, fires and hurricanes may result in a catastrophic destruction of vast forest areas, which give rise to new successions. Hence, the climax forest is, in this case, less stable; however, the instability is not a question of competition, but rather a result of destruction.

4) Pioneer species and climax species (cp. also Morosow*)).

*) When this paper was already in proof I encountered Morosow's book. I regret that it was impossible, at this late stage, to make use of the discussions in that stimulating work. 
The word "climax" species does not indicate that these tree species are better adapted to the climate in which they grow than any other species that thrives and reproduces itself there. But owing to their competitive character they may form stable communities, not only successional stages as in the case of the pioneer species. A forest of climax trees may be superseded by pioneer trees only after forest destruction (e. g. resulting from hurricane or forest fire, cf. note 3 ).

Man's activities in the forest (thinning and clearing before the stands are mature) reduce the influence of natural competition between the tree species, and the difference between climax species and pioneer species is obscured.

5) Light requirements of tree species.

Since Vaupell's time the chief progress in the study of the light requirements of the tree species in nature is due to Boysen JENSEN $(1929,1949)$, who introduced exact light measurements. The following brief survey is mainly based on his observations.

Three different types of morphological adaptions to shade may be distinguished. 1) Adaptions found in leaf anatomy ("shade leaves"), 2) adaptions in the arrangement of leaves ("leaf mosaik"), and 3) adaptions in the shoot architectony, which enables the species to develop harmonious suppressed shade trees that may persist for 100 years and more in the shade of a canopy. Our typical shade tolerant tree species have all three types of adaptions: Fagus, Tilia, Ulmus, Carpinus, Corylus; also the conifers Taxus and Abies pectinata. The two first mentioned adaptions, but not the third, are found, e. g. in Acer pseudoplatanus and Acer platanoides; these species are very shade tolerant when young, less so when older. Fraxinus has only the first type of adaption; it must be classified under the "light trees", though young ash plants are shade tolerant, contrary to young plants of typical light trees, such as Betula.

A fact of fundamental importance is that the light requirements of the same species change during life: young plants are more tolerant than old trees. Hence old stands of a tree species are less shady than young stands, and light is sufficient for regeneration in old stands of shade tolerant trees already some time before the latter die of old age. At the same time root competition diminishes, while their fruits become abundant. That explains the fact that under natural conditions climax forests may continue unchanged generation after generation, as observed in virgin forests.

The importance of the light factor has been rejected by some authors owing to the fact that also root competition is a delimiting factor for regeneration in a dense forest. Though the latter is true it does not at all reduce the importance of the light factor as indeed subsequent tests have proved (cf. Dengler 1. c., p. 124).

6) Incomplete immigration.

While in Southern Germany hazel, elm, oak, lime and alder immigrate more or less at the same time (see Firbas, p. 370), there is an increasing difference in the time of arrival when we move northward. In Denmark hazel immigrates much earlier than the others; lime and alder are the latest arrivals, they immigrate at the same time as Hedera and Viscum. In England, Norway and Middle Sweden Tilia is even later, both in oceanic and continental regions. Thus in the Oslo-region Tilia arrives distincly later than Hedera and Viscum (HAFSTEN 1956), which demonstrates that the late appearance of Tilia cannot be due to climatical factors.

In sharp contrast to conditions in Northern Europe the warmth-demanding tree species immigrate quickly in North America; no serious obstacles impede immigration in this region.

7) Unfortunately we know nothing about the respective immigration date of the two oak species (Quercus robur and Quercus petraea). If one of these species immigrated later than Tilia, this fact too has to be considered when discussing the remarkable Quercus curve in Allantic time (see the discussion p. 11). Von Post (1924) and others have gone into this problem and have postulated a very late arrival of Quercus petraea. Unfortunately, so far it has not been possible to identify with any degree of certainty the pollen of oak as to species; the shape of the grain has been considered, but since it is greatly affected by chemical treatment of sample (Brorson Christensen 1946) this method is not reliable.

8) Most authors are of different opinion. There is no need to discuss the problem thoroughly because $\mathrm{C}_{11}$-datings will soon give the answer. 
9) Quercus robur attains optimal growth on the rich moist soils of the "Auenwälder" which are submerged by the rivers in spring (e. g. the famous oak forests in Slavonia). On the other hand it may also grow on poor soils, but here it is much reduced in size and vigour (see e. g. KøIE 1951). In October 1957 I had an opportunity to study the distribution of the forest trees in South Tessin (Locarno region). Here Quercus robur was only found on the moist river plains, where it was common, while Quercus petraea was restricted to the acid mountain slopes, rocks elc. Tilia, chiefly Tilia cordata, grew on both soils, though planted Castanea usually replaced Tilia and Quercus petraea in the mountains, except in steep, rather inaccessible localities. Where the soil was not too shallow and poor, Quercus petraea was easily suppressed by Tilia. At higher altitude both species and Castanea too were replaced by Fagus.

Many authors claim that Quercus petraea is more shade resistant than Quercus robur; this is also indicated by the fact that in contrast to Quercus robur the leaves in Quercus petraea are arranged in a flat mosaik. Details of the ecology of Quercus robur and Quercus petraea are given by Weimark (1947), Tansley (l. c.), Pearsall (l. c.) and the books mentioned in note one.

10) In the British Isles Tilia has been of less importance, perhaps because Ulmus glabra and Quercus petraea are more competitive in oceanic regions. The great frequency of Ulmus in Irish pollen diagrams is remarkable. Here the "Mixed Oak forest" consisted of Ulmus (glabra) and Quercus (petraea) only, and Morrison's (1959) theory that these species because of contrasting soil needs had grown as separate associations is in all probability right, even if we may assume that both Quercus petraea and Ulmus glabra had a wider edaphic range in Ireland, owing to the absence of competition from Tilia.

11) Pollen production and dispersal of Tilia.

PoHL (1937) and Hyde (1945) have demonstrated that lime has a great pollen production when growing under favourable light conditions, such as in parks. However, when lime grows in a dense forest, flowering is greatly reduced; presumably even more so than is the case in other deciduous tree species, because lime flowers at a time when the tree is densely covered with leaves.

Our observations in Draved show that Tilia may be under-represented in acid humus even immediately beneath lime-trees, though of course less so than in peats, where macroscopical pollen transport is excluded. Despite the frequency of lime in Draved, Tilia pollen is rare in Sub-atlantic peat deposits inside and outside the forest. Our observations, accordingly, support the findings of Hesmer (1933), Rempe (1937) and others that Tilia is seriously under-represented in the pollen flora of sediments, as indeed many students of forest history have supposed. If we double the Tilia counts prior to calculation of the percentages this deficiency may be reduced.

12) The tiny bog Hertugdalen (diameter $25 \mathrm{~m})$ and the small lake Gribsø $(600 \mathrm{~m} \times$ $200 \mathrm{~m}$ ), both in Grib skov, N. Zealand. Mean percentages of the two provisional analyses from Hertugdalen are compared with mean percentages from two corresponding analyses from Gribsø (from Wolthers 1956). Corylus, Betula, Alnus, and Pinus divided by 4 prior to calculation.

\begin{tabular}{|c|c|c|c|c|}
\hline & Hertugdal & Gribsø & Hertugdal & Gribs $\emptyset$ \\
\hline 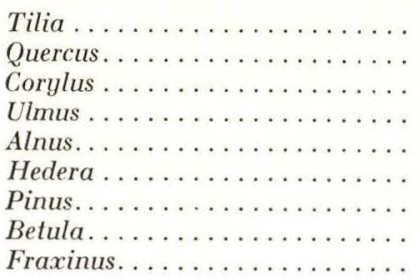 & $\begin{array}{r}53 \\
21 \\
9 \\
8 \\
5 \\
2 \\
2 \\
1\end{array}$ & $\begin{array}{c}20 \\
44 \\
9 \\
14 \\
8 \\
0,2 \\
1 \\
2 \\
1\end{array}$ & $\begin{array}{r}118 \\
47 \\
20 \\
18 \\
11 \\
4 \\
4 \\
2\end{array}$ & $\begin{array}{l}25 \\
55 \\
11 \\
17,5 \\
10 \\
0,25 \\
1 \\
2,5 \\
1\end{array}$ \\
\hline Pollen total. . . . . . . . . . . . . & 479 & 1256 & & \\
\hline
\end{tabular}


On the right the percentages are based on the pollen total from anemophilous trees only. It appears that the analyses from Hertugdalen are very similar to those from Gribsø, except that the insect-pollinated trees Tilia and Hedera have much higher pollen percentages. Similarly Hesmer (1935) demonstrated that macrofossils of Tilia were frequent in deposits of very small lakes (in Atlantic or Sub-boreal time).

13) To-day Tilia is, in Denmark, most frequent on rather moist clay soils, but this is due, no doubt, to the fact, that the lime that occured on well drained fertile soils was replaced long ago by other trees, especially beech.

VAupell (1863, p. 168) describes a lime forest near Copenhagen on fertile hilly ground (Egebjergene, Jonstrup Vang), which had to be changed into a beech forest, according to the usual practice in state forestry. However, the resistance of lime was very strong. Self-sowing of beech was made impossible because the ground was covered by lime (suckers and stub shoots). Indeed, it was not possible to cultivate beech until all lime had been removed from the ground.

Though Tilia - contrary to Fagus - grows well on moist fertile gley soil, it is less resistant to the water-level changes of low-lying soils than Quercus robur and Alnus glutinosa. In the very dry summer of 1959 we observed in Draved that Tilia and Fagus suffered seriously from drought, when growing on places where the water-table normally is high. Their root-systems were obviously very shallow in this soil, and the water-table had sunk to a level beneath the reach of the roots. Fraxinus was less affected, and Quercus robur and Alnus glutinosa did not suffer at all. The crowns of the latter species were covered with large and dark green leaves, while the leaves of Tilia were very small; they turned yellow already in July, and a great deal of them dropped to the ground. Lime trees that grew on high ground did not suffer.

14) Soil degradation dated by pollen analysis and radio-carbon.

Thick layers of purely organic acid forest humus ("mor-peat", a terrestric sediment) are only described in the literature as an exception. Trautmann (1952) has demonstrated their common occurence in the Bayrischen Alpen and has, based on pollen analysis, estimated the age of the thickest layers to be about 2500 or 3000 years. Similar high age has also been reported from alpine terrestric raw-humus (WELTEN 1958), from Western Norway (FæGRI 1954) and from Denmark (Iversen 1958). In soil litterature this type has been described as oak-mor (P. E. Müller 1884) or Moder (e. g. KubiëNa 1950). Apparently nobody has imagined that their age could be so high, until it was demonstrated by pollen analysis. One might challenge this dating; however, $\mathrm{C}_{14}$-dating has confirmed it. From a $40 \mathrm{~cm}$ thick oak-mor layer (covered by $20 \mathrm{~cm}$ of heath-mor) in Draved (cp. table 1) two samples were collected. The deepest sample was taken from a stripe of charcoal (oak), $25 \mathrm{~cm}$ above the mineral soil. Mr. Henrik Tauber, civil engineer, at the Copenhagen Dating Laboratory, has dated these charcoal bits as from 450 B.C. \pm 100 . The next sample was from a stripe of oak-bark, $8 \mathrm{~cm}$ higher up. Mr. TAuber dated it to be $50 \mathrm{~A}$.D. \pm 100 . Since $25 \mathrm{~cm}$ of extremely decomposed mor was found beneath the charcoal layer from 450 B.C., we may estimate that the mor-formation began about 2000 B.C. A pollen analysis from the mor adjacent to the mineral soil (bleached sand) indicates that the strong podsolization commenced in a dense oak forest, untouched by man (table 1, no. 6). This may be an exceptional case; normally podsolization in oak forest seems to have set in as a result of forest destruction (Dimbleby \& Gill 1955).

In our Calluna heaths one might expect thick layers of mor-peat. No doubt, this would have been the case, if systematic cutting of "lyngtørv" (heath-peat) and heath burning had not been practiced from time immemorial.

15) Figures 2-4. The figures were built up in the following way.

1. The pollen percentages of the tree species were calculated on the basis of the pollen total of trees, shrubs and herbaceous plants; prior to calculation the pollen number of Betula, Pinus, Corylus and Alnus was divided by four, while the number of Tilia and Hedera was doubled.

2. The analyses within each pollen series were grouped according to increasing, culminating and decreasing Plantago percentage ( 8 groups), as shown in the figures.

3. Within each group the average pollen percentage for all analyses was calculated for each tree species. 
4. The average pollen percentages of (usually four) analyses immediately prior to the very first appearance of pollen grains of reliable indicators of farming culture in Denmark (Plantago major, Plantago lanceolata, cereals) are taken as characteristic of the virgin forest. Hence the ratio between that percentage and the percentage of the following groups is calculated; those indices demonstrate the influence of farming culture on the relative frequency of the individual tree species in each diagram.

5. For each tree species the mean is calculated for those indices from all localities within each of the groups (of increasing and decreasing Plantago lanceolata frequency).

6 . The highest mean index thus obtained is, for each species, put at 100, and the others given as percentages of this figure.

16) Troels-Smith (1960) points out that mistletoe is very valuable for fodder, and there is no doubt that also people of the stone age utilized it to the best of their ability. It remains questionable, nevertheless, whether the species can have been affected much by this practice. When growing in a dense forest mistletoe is very difficult to reach. Particularly in the rather dark lime forest it grows almost exclusively on the thin branches of the uppermost parts of the tree crowns because light is adequate only here. In the coppice it can, however, be picked easily. The lateral pollen dispersal of the mistletoe is presumably just as poor as that of the lime; hence, when the forest round a lake is cleared, both lime and mistletoe will have a more pronounced decline in pollen frequency than other tree species, the pollen of which is dispersed more effectively. The proper procedure, also from this point of view, will be to calculate the pollen frequency of mistletoe chiefly in relation to that of lime, as done by Troels-Smith (1960). In Atlantic and Sub-boreal time lime was no doubt the most important host of mistletoe, whereas the species is hardly ever found as a parasite on oak, elm or alder.

17) According to JesSEN (1949) Ilex pollen was frequent already in Irish deposits from Atlantic time, in contrast to what is known from S-England. We may assume that Ilex in Ireland has formed pure stands, in which case pollen dispersal is improved.

18) The Blytt-Sernander scheme of climatic development has not been confirmed by pollen analysis. The terms Atlantic and Sub-boreal are to-day solely used as convenient names for pollen statistical zones (VI + VII, and VIII, respectively, in JEssEN's zonation system). 


\title{
Literature
}

\author{
D.G.U. = Danmarks Geologiske Undersøgelse.
}

Becker, C. J., 1948: Mosefundne Lerkar fra Yngre Stenalder. Dissert. København. Brockmann-Jerosch, H., 1936: Futterlaubbäume und Speiselaubbäume. Ber. Schweiz. Bot. Ges. 46.

Christensen, B. Bronson, 1946: Measurements as a means of identifying fossil pollen. D.G.U. IV. series, vol. 3, 2.

Clements, F., 1916: Plant Succession. Carnegie Institution of Washington, 290.

Degerbøl, M. \& Krog, H., 1951: Den europæiske Sumpskildpadde (Emys orbicularis L.) i Danmark. D.G.U. II. series, no. 78.

Dengler, A., 1935: Waldbau auf ökologischer Grundlage. 2. Aufl. Berlin.

Dimbleby, G. W. \& Gill, J. M., 1955: The occurrence of podzols under deciduous woodland in the New Forest. Forestry. Vol. 28, no. 2.

Firbas, F., 1949: Waldgesehichte Mitteleuropas I. Jena.

Florin, M.-B., 1957: Pollen-analytical evidence of prehistoric agriculture at Mogetorp Neolithic settlement, Sweden. In Florin, Sten. Vråkulturen. Kungl. Vitterhets Historie och Antikvitets Akad. Stockholm.

Franks, J. W., 1957: Pollen analysis: a technique for investigating early agrarian history. Agric. Hist. Rev.

Fries, M., 1958: Vegetationsutveckling och odlinģshistoria i Varnhemstrakten. En pollenanalytisk undersökning i Västergötland. Acta Phyt. Suecica. 39.

Fköнlich, Jul., 1930: Der südosteuropäische Urwald und seine Üherführung in Wirtschaftswald. Centralbl. f. d. gesamte Forstwesen 56.

FÆGRI, K., 1940: Quartärgeologische Untersuchungen im westlichen Norwegen. II. Zur spätquartären Geschichte Jærens. Bergens Mus. Årb. 1939-40. naturv. r. no. 7.

- 1944: On the introduction of agriculture in western Norway. Geol. Fören. Förh. 66 , H. 3.

- 1954: On age and origin of the beech forest (Fagus silvatica L.) at Lygrefjorden, near Bergen (Norway).

Godwin, H., 1929: The sub-climax and deflected Succession. Jour. of Ecology. Vol. 17.

- 1956: The history of the British flora. Cambridge.

Grohne, U., 1957: Zur Entwicklungsgeschichte des ostfriesischen Küstengebietes auf Grund botanischer Untersuchungen. Probleme der Küstenforschung im südlichen Nordseegebiet. Bd. 6.

Hafsten, U., 1957: Pollen-analytic investigations on the late-Quaternary development in the inner Oslofjord area. Univ. Bergen. Årb. 1956. Naturv. r. no. 8.

Hesmer, H., 1933: Die natürliche Bestockung und die Waldentwicklung auf verschiedenartigen märkischen Standorten. Z. f. Forst- u. Jagdwesen, 65.

- 1935: Samen- und Knospenschuppenanalysen in Mooren. Z. f. Forst- u. Jagdwesen, 67.

Hyde, H. A., 1945: Pollen of lime (Tilia ssp.). Nature 155, p. 457.

IverseN, Johs., 1941: Landnam i Danmarks Stenalder. D.G.U. II. series, no. 66.

- 1944: Viscum, Hedera and Ilex as climate indicators, Geol. Fören. Förh. Bd. 66, H. 3.

- 1949: The influence of prehistoric man on vegetation. D.G.U. IV. series, Vol. 3. no. 6 .

- 1958: Pollenanalytischer Nachweis des Reliktencharakters eines jütischen LindenMischwaldes. Veröff. d. Geobot. Inst. Rübel in Zürich, H. 33. 
Jensen, P. Boysen, 1929: Studier over Skovtræernes Forhold til Lyset. Dansk Skovforen. Tidsskr. 1929.

- 1949: Causal plantgeography. Biol. Medd. Dan. Vid. Selsk. 21, no. 3.

Jessen, Knud, 1949: Studies in late Quaternary deposits and flora history of Ireland. Proc. Royal Irish Acad. Vol. 52, Sect. B. no. 6.

Jörgensen, Svend, 1954: A pollen analytical dating of Maglemose finds from the bog Aamosen, Zealand. D.G.U. II. series, no. 80.

Kirchner, O. v., Loew, E., Schröter, C., etc., 1908 and later: Lebensgeschichte der Blütenpflanzen Mitteleuropas. Stuttgart.

Krog, H., 1960: Post-glacial submergence of the Great Belt dated by pollen-analysis and radiocarbon. Intern. geol. Congr. Report of the 21st session Norden 1960. Part IV. Proc. of Sect. 4. (In print).

KubiËNA, W. L., 1950: Bestimmungsbuch und Systematik der Böden Europas. Stuttgart.

Køıє, M., 1951: Relations of vegetation, soil and subsoil in Denmark Dansk Bot. Arkiv, Vol. 14 , no. 5 .

Markgraf, F. \& Dengler, A., 1931: Aus den südosteuropäischen Urwäldern. Z. f. Forst- u. Jagdwesen, 58 .

Mauve, K., 1931: Ueber Bestandesaufbau, Zuwachsverhältnisse und Verjüngung im galizischen Karpaten-Urwald. Mitt. aus Forstwirtschaft und Forstwiss. II.

Mikkelsen, V. M., 1949: Præstø Fjord. The development of the postglacial vegetation and a contribution to the history of the Baltic Sea. Dansk Bot. Arkiv, Vol. 13, no. 5.

Morosow, G. F., 1928. Die Lehre vom Walde. (Translated from Russian). Neudamm.

Morrison, M. E. S., 1959: Evidence and interpretation of "landnam" in the North-East of Ireland. Bot. Not. Vol. 112, no. 2.

Mülı.er, P. E., 1884: Om Muld og Mor i Egeskove og på Heder. Tidsskr. f. Skovbrug. VII.

Nordhagen, Rolf, 1954: Om barkebrød og treslaget alm i kulturhistorisk belysning. D.G.U. II. series, no. 80 .

Pohl, F., 1937: Die Pollenerzeugung der Windblütler. Beih. Bot. Cbl. 56/A.

Post, L. v., 1924: Ur de sydsvenska skogarnas regionala historia under postarktisk tid. Geol. Fören. Förh. Jan.-Febr. 1924.

Rempe, H., 1937: Untersuchungen über die Verbreitung des Blütenstaubes durch die Luftströmungen. Planta. Vol. 27, no. 1.

RubNER, K., 1935: Die pflanzengeographischen Grundlagen des Waldbaus. 3. Aufl.

Sмгтн, A. G., 1958: Pollen analytical investigations of the mire at Fallahogy Td., Co. Derry. Proc. Royal Irish Acad. Vol 59, Sect. 5.

Tansley, A. G., 1949: The British Islands and their vegetation. Cambridge.

Trautmann, W., 1952: Pollenanalytische Untersuchungen über die Fichtenwälder des Bayrischen Waldes. Planta. 41.

Troels-Smith, J., 1954: Ertebøllekultur-Bondekultur. Resultater af de sidste 10 års undersøgelser i Åmosen. Årb. f. Nordisk Oldkyndighed og hist. 1953.

- 1955: Pollenanalytische Untersuchungen zu einigen schweizerischen Pfahlbauproblemen. Das Pfahlbau-problem. Schaffhausen 1954.

- 1960: Ivy, Mistletoe and Elm. Climate Indicators - Fodder Plants. D.G.U. IV. Series. Vol. 4. No. 4. (In print).

Vaupell, C., 1863: De danske Skove. København.

Walter, H., 1954. Klimax und zonale Vegetation. Veröffentl. Kärntner Landesinst. f. angewandte Pflanzensoziologie in Klagenfurt. Festschr. Aichinger. 1. Bd. 1954.

Waterbolk, H. T., 195s: Pollen spectra from Neolithic grave monuments in the northern Netherlands. Palaeohistoria. Vol. 5.

Welten, Max, 1958: Pollenanalytischer Untersuchung alpiner Bodenprofile: historische Entwicklung des Bodens und säkulare Sukzession der örtlichen Pflanzengesellschaften. Veröff. d. Geobot. Inst. Rübel in Zürich. H. 33.

Wermarck, H., 1947: Bidrag til Skånes flora. 18. Distribution and ecology of Quercus petraea. Bot. Not. 1947.

Wolthers, Per, 1956: Pollenanalytical studies of the profundal dygyttja in Gribsø. Folia Limnologica Scandinavica, no. 8.

ZEIST, W. v., 1959: Studies on the post-boreal vegetational history of south-eastern Drenthe (Netherlands). Acta Bot. Neerlandica 8. 


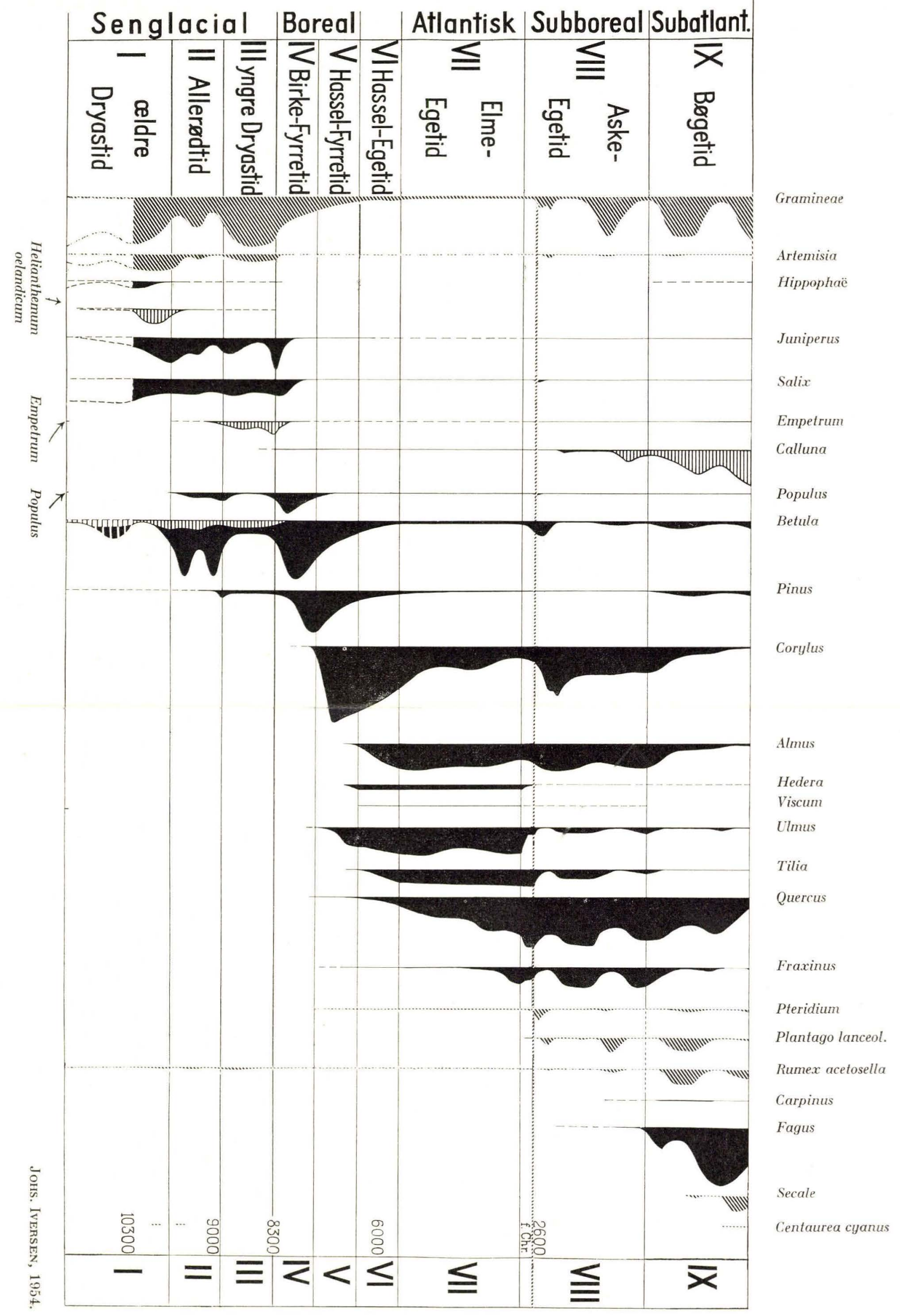

Fig. 7. Schematic pollen diagram characteristic of Jutland showing the Late- and Post-glacial vegetational development. Oblique hatching: herbaceous plants; horizontal hatching: dwarf shrubs; black in Denmark as an excetion (Lake Bölling); the birch maximum in the middle of zone I reflects the in Denmark as an exception (Lake Bolling it divides zone I into three subzones (Ia Ib Ic). The late-glacial part of the bireh silhouette comprises Betula nana (hatched silhouette, small pollen grains) in addition to tree-birches. 